\title{
Kids’ Empathic Development Scale: Turkish Language Validity and Reliability
}

\author{
Marilena Z. Leana-Taşc1lar ${ }^{1}$, Mahir Biber ${ }^{2} \&$ Tunç Kurt $^{3}$ \\ ${ }^{1}$ Special Education Department, Istanbul University-Cerrahpaşa, Istanbul, Turkey \\ ${ }^{2}$ Primary Education Department, Istanbul-University-Cerrahpaşa, Istanbul, Turkey \\ ${ }^{3}$ High School Teacher, Bahcesehir College, Istanbul, Turkey \\ Correspondence: Marilena Z. Leana-Taşcılar, Special Education Department, Istanbul University-Cerrahpaşa, \\ Besim Omer Pasa Cad. B Blok, Istanbul, Turkey.
}

Received: June 28, 2018

Accepted: July 27, 2018 Online Published: September 6, 2018

doi:10.5539/jel.v7n6p111

URL: https://doi.org/10.5539/jel.v7n6p111

This study was supported by BAP department of Istanbul University, in the frame of the project number SYD-2017-25598.

\begin{abstract}
Empathy is one of the skills that we need in order to understand the emotions of other people. Although many empathy scales exist, few are designed for children. The Kids' Empathic Development Scale (KEDS) can be applied onward of age 6 and provide information about empathy's affective, cognitive and behavioural components. The aim of this study is to present the Turkish validity study of KEDS and to provide a new tool that has satisfactory psychometric properties. Nine language experts made the translation and back translation form English to Turkish and vice versa. After that, the experts asked to rate the translation validity. According to experts' opinions, the appropriate level of the items in the scale varied between 4.60 and $5.00(\bar{X}=4.80, \mathrm{SD}$ $=.44)$. The results indicated that the Turkish scale closely approximated with the original. The scale's language validity, analyses were performed on 30 ( 21 girls, 9 boys, average age $=9.5, \mathrm{SD}=1.17$ ), bilingual students. Analysis, which was performed between the English and Turkish forms, showed that only the item I7_1 was found out to be problematic. Afterward, the scale's language validity was ensured and easily accessible sampling method was adopted, and then it was applied to 293 (144 girls, 149 boys) students who were attending in seven different schools (four public, three private). Correlation analysis, which was performed to test concurrent validity, showed that there is a positive correlation $(\mathrm{p}<.01)$ between the total scores of Children's Empathy Scale and Kids' Empathic Development Scale. The results of variance analysis, which were performed in order to test if the empathy scores vary according to age, were significant as follows: total empathy score $\mathrm{F}(4,248)=$ $3.10, \mathrm{p}<.05$, affective $\mathrm{F}_{(4,251)}=4.70, \mathrm{p}<.01$, cognitive $\mathrm{F}_{(4,250)}=2.6, \mathrm{p}<.05$ and behavioural $\mathrm{F}_{(4,248)}=4.09, \mathrm{p}$ $<.01$. Taking into consideration the gender variable not significant results were obtained. The results of the study showed that the Turkish version of KEDS is a valid and reliable, and has acceptable psychometric properties.
\end{abstract}

Keywords: empathy, kids' empathic development scale, language adaptation, validity, reliability

\section{Introduction}

Empathy is defined as the skill of an individual's ability to understand and share the feelings of others (Davis, 1980). According to Adler, empathy is seeing with the eyes of another, listening with the ears of another, and feeling with the heart of another (Demetriou, 2018). It is also viewed as an important part of communication (Barnett, 1990). Lack of empathy is associated with antisocial behavior, bullying, autism, personality disorders and psychopathology (Gini, Albiero, Benelli, \& Altoe, 2007; Lombardo, Barnes, Wheelwright, \& Baron-Cohen, 2007). Goleman (2000) stated that empathy is an important component of emotional intelligence. In the educational context, it is even more important to take into account the research on empathy.

Theorists have often associated the development of empathy with cognitive skills such as perspective taking. As Bischof-Köhler (1991) mentioned, at the age of 3, children begin to identify some emotions properly, but their performance remains imperfect up to the age of 6. Feshbach (1978) pointed out that empathy will not be 
expected to occur in children younger than 5 years of age. However, recent studies reveal that early signs of empathy can be observed in infants aged 8-16 months (Roth-Hanania, Davidov, \& Zahn-Waxler, 2011).

Goleman (2000) reported that the roots of empathy can be traced to infancy. The neurons, which respond to affective expressions in infancy, are the first form of empathy in the nervous system. Virtually from the day they are born, infants are upset when they hear another infant crying - a response that some see as the earliest precursor of empathy. The imitation of movement starts in the first two years of life. It is thus easier to understand how someone else feels. The displays of understanding and imitating the feelings of others as well as the desire to help them occur at two to three years of age (Zahn-Waxler, Radke-Yarrow, Wagner, \& Chapman, 1992). After three years of age, children start to realize that their thoughts are different from those of others and only after six years of age, they are starting to see events from the point of view of others (Shapiro, 2000).

Eisenberg and Fabes (1990) noted that empathy has two aspects: the affective and the cognitive. Affective aspect of empathy refers to having an affective response congruent with that of another's emotional state, whereas cognitive aspect of empathy refers to ability to understand intellectually the perspective of another person and, in so doing, understand another's emotional state (Davis, 1980). However, an empathetic response is also held to involve not only understanding the feelings of others but also being appropriately responsive (Cappadocia, Pepler, Cummings \& Craig, 2012). For this reason, in recent studies, it has been argued that in addition to affective and cognitive aspects of empathy, behavioural aspects also should be examined (Reid et al., 2012). Although empathy is theoretically considered to be composed of three components, measurement tools are being newly developed to evaluate these components (Reid et al., 2012).

\subsection{Models of Empathy}

Early research proposed empathy as a single dimension. Later on, empathy was proposed as multidimensional model (Costa, Glinia \& Drakou, 2006). Feshbach and Kuchenbecker (1974), Davis (1980), Dökmen (1997) and Hoffman (2000) are some of the researchers who proposed multidimensional models of empathy. Feshbach and Kuchenbecker (1974) suggested a three-component model of empathy that consists of two cognitive components: the ability to discriminate and label affective states in others, and the ability to assume the perspective and role of another person. The third component is emotional responsiveness. As the child grows, the ability to comprehend social situations increases, as does the tendency to share the affective state of individuals in these social situations. The social comprehension factor becomes associated with the remedial progress in achievement of the child, while empathy becomes more strongly associated with social behavior.

Another researcher that proposed a model of empathy is Davis (1980). According to Davis (1980) empathy is a multidimensional phenomenon, which consists of four components: empathic concern, fantasy, personal distress, and perspective taking. Empathetic concern described as 'other-oriented' feelings of sympathy and concern for unfortunate others, while fantasy taps individuals' tendencies to transpose themselves imaginatively into the feelings and actions of fictitious characters in books, movies etc. Personal distress focuses on 'self-oriented' feelings of personal anxiety and unease in tense interpersonal settings. Perspective taking is described as the tendency to spontaneously adopt the psychological point of view of others. Davis (1980) developed a 28-item questionnaire based to his empathy model, which provides an efficient way of measuring emotional and cognitive role taking.

Dökmen (1997), suggested the staged empathy classification, that consisted of the stages: they, I and you. In 'They' stage the individual understands what people in the society are thinking and feeling about the problems of others, in the 'I' stage, the individual understands what he/she is thinking and feeling about the problems of others and the last stage 'You' the individual understands what other people are thinking and feeling about problems of others. The person responding at the 'They' stage always makes evaluations based on society's judgments rather than focusing on the problem. In the 'I' stage, one responds to the criticism of another, giving advice and evaluating the problem according to one's own interpretation, and transferring one's own feelings and experiences regarding that subject. The 'You' stage involves putting oneself into another's place to understand the problem, reflecting what is understood by the other, supporting the individual, and understanding deep feelings.

Hoffman (2000) suggested a theory that accounts for human action in five types of moral encounters or dilemmas: an innocent bystander, transgressor, virtual transgressor, multiple moral claimants and caring versus justice. According to Hoffman (2000), all five types share an empathic motive base. Each type features empathic distress - one feels distressed on observing someone in actual distress - and one or more motives derived from empathic distress: sympathetic distress, empathic anger, empathic feeling of injustice, guilt. Hoffman (2000) in his model also explains the development of empathic distress in children in five stages: reactive newborn cry, 
egocentric empathic distress, quasi-egocentric empathic distress, veridical empathic distress and empathy for another's experience beyond the immediate situation.

As it is seen all of the aforementioned models emphasize the different dimensions of empathy. In conclusion, according to several models of empathy, empathy is seen as an important component of the cognitive development, thus it is important in the school life of a child.

\subsection{The Importance of Empathy in Education}

Empathy is a key element of positive classroom environment (Mozakoğlu, 2015). Studies held by Cooper (1997), showed that empathy is one of the five most important traits that a teacher must have. In another study, he also found that the higher empathy ability the teacher had, the more the students were able to understand more complex concepts (Cooper, 2011). Most of the research done in this field investigated teacher empathy levels. However, empathy is a concept that should be examined in students, as well.

Empathy is an attribute of children that affects the educational process and educational outcomes (Feshbach \& Feshbach, 2009). As mentioned above, the interest of educators in empathy has historically centered on teacher empathy. Empathy level of students is essential for academic learning and achievement, thus the focus of the new studies becomes the students. The empathy skills in children associated with social understanding, emotional competence, prosocial and moral behavior, compassion and caring, and regulation of antisocial behaviors (Feshbach \& Feshbach). All these skills are important factors that affect the educational environment of the student.

The aforementioned skills are character based traits, which affect learning, thus the school wants to increase them. Studies conducted by Booner and Aspy (1984) supported the fact that empathy has an effect on academic success. Especially in courses such as literature, students have the opportunity to identify themselves with the characters of the story and this leads to a better understanding of the topic and that contributes to academic success. Feshbach and Feshbach (1987)'s empirical studies showed that teaching students about empathy effects academic success. Moreover, studies such as the one that conducted by Yüksel (2003) and Gemci (2012) revealed that it is possible to improve students' empathy skills using training programs on empathy.

\subsection{Recent Studies on Empathy}

Positive effects of empathy to school environment and psychological wellbeing of the students motivate the researchers to conduct new studies on empathy. In a recent study by Gini, Albiero, Benelli, and Altoe (2007), results revealed that low levels of empathic responsiveness were associated with students' involvement in bullying others. In contrast, empathy was positively associated with actively helping victimized schoolmates. The findings confirm and extend the literature on the relationship between empathy, prosocial, and aggressive behaviors.

The gain of empathy skills is also an important topic in studies with autistic individuals. The lack of empathy is one of the important features of autism disorder. Based on this, Schrandt, Townsend, and Poulson (2013) conducted a study that aimed to teach empathetic responding to 4 children with autism. According to this study, instructors presented vignettes with dolls and puppets demonstrating various types of affect and used prompt delay, modeling, manual prompts, behavioural rehearsals, and reinforcement to teach participants to perform empathy responses. Increases in empathetic responding occurred systematically with the introduction of treatment across all participants and response categories.

Another study examined the role of empathy and self-regulation as mediators between positive parenting and early adolescents' prosocial behavior toward 3 targets (strangers, friends, and family). Analyses that made with the data collected from 500 families suggested that predictors of prosocial behavior toward the 3 targets differed, with empathy and self-regulation mediating the relation between positive parenting and prosocial behavior towards strangers and friends, but not toward family (Padilla-Walker \& Christensen, 2010).

There are also numerous studies that support the hypothesis that empathy is a skill that can be developed with different training programs. Such a research is the one that conducted by Yüksel (2004). According to her study, empathy training program increased the empathic ability level of primary school students. Yüksel (2004) developed an empathy training program depended on role-playing, informing and modeling, based on the empathy model developed by Dökmen (1997). Bal and Bilge (2016), examined the effects of 'Empathy Skills Psycho Training Program' on the gifted adolescents. Researchers concluded that the applied training program affected the empathy skills of gifted adolescents positively and led to an increase in their empathy scores. Last but not least, study by Kurt (2018) showed that it is possible to enhance gifted children's empathy levels by using a bibliotherapy based training program. 


\subsection{Measuring Empathy in Children}

The literature review revealed that most of the scales developed to assess empathy are designed for adults instead of children. Gürtunca (2013) adapted Bryant's (1982) Empathy Scale for Children and Teenagers into Turkish. This scale, comprising of 22 items, is appropriate for students between the ages 8 and 14. Kaya and Siyez (2010) developed KA-SI, a measurement tool specific to the Turkish culture to evaluate the empathic tendencies of children and teenagers. KA-SI is comprised of two dimensions, namely cognitive and affective empathy, and two forms: children $\left(3^{\text {rd }}-5^{\text {th }}\right.$ grade $)$ and teenager $\left(6^{\text {th }}-12^{\text {th }}\right.$ grade $)$.

Raine and Chen (2017) recently developed a self-report instrument- CASES, to assess the three aspects of empathy in children. As the authors mentioned their intention was to create a scale that could globally capture various facets of empathy in a single assessment tool. The CASES model is one among several multidimensional models of empathy that consist of cognitive, affective and somatic empathy. The results of the study showed that they developed a brief (30-item) empathy scale with good sampling and face validity that can be used with children and adolescents.

Jolliffe and Farrington (2006) developed the Fundamental Empathy Scale which relies on four fundamental feelings (fear, sadness, anger, joy). This scale is appropriate for teenagers (who aged 10 - 15) and it consists affective and cognitive empathy components. However, there is no Turkish adaptation of this scale. Empathic Tendency Scale which was developed by Dökmen (1988) for adults was adapted for eighth-grade students by Gökler (2009) and it evaluates empathic tendencies.

When the various studies that have been conducted into empathy in Turkey are examined, it will be seen that there is a need in our country to evaluate empathy, especially for young children. Those empathy-related studies that have been carried out in Turkey have generally focused in explaining the term itself and to develop new scales for older children and adults; by contrast the number of studies for young children have been extremely limited. As stated above, empathy is a skill that children acquire very early and it is important for their academic success and school life. Thus, the aim of this study is the adaptation of Kids' Empathic Development Scale (developed by Reid et al. (2012), and measures not only the affective and cognitive aspects of empathy like other scales but also the behavioural aspect, and can be applied to children of age six and up), into Turkish. The evaluation of empathy levels of children according to scenarios, separates the scale from other pen and paper and Likert type scales.

\section{Method}

The study used a scanning method (Karasar, 1994). A quantitative method was conducted in this study. Data was collected through the scale adapted into Turkish and another empathy scale named Empathy Scale for Children and Teenagers.

\subsection{Working Group}

Different working groups have been included in the process at different stages. The working group was determined through purposive sampling, which is useful option when the desired population for the study is rare or very difficult to locate and recruit (İşçil, 1973). 5 language experts helped with the translation and back translation of the scale. Teaching assistants from Foreign Languages and Turkish Education departments of universities and experienced English and Turkish teachers were asked to translate the scale. The scale's language validity, analyses were performed on $30(21$ girls, 9 boys, average age $=9.5, \mathrm{SD}=1.17)$ bilingual primary school students who speak Turkish and English as their native language. To investigate the language equivalency of the Turkish version of the scale, first the English form and 3 weeks later the Turkish form were administered to the bilingual students.

The easily accessible sampling method (Yıldırım \& Şimşek, 2008) was adopted for Turkish validity reliability studies. In total 293 students attended in seven different schools (four public, three private) took part in the study. The students, whose parents were informed about the study, were volunteers and received nothing for their participation in the study. 62 of these students were attending $1^{\text {st }}$ grade $(27$ girls, 35 boys, average age $=6.85$, SD $=.50), 90$ were attending $2^{\text {nd }}$ grade $(42$ girls, 48 boys, average age $=7.88, \mathrm{SD}=.35)$, 64 were attending $3^{\text {rd }}$ grade ( 32 girls, 38 boys, average age $=9.01, \mathrm{SD}=.61)$ and 77 were attending $4^{\text {th }}$ grade $(43$ girls, 34 boys, average age $=9.90, \mathrm{SD}=.34)$ by the time of the study. The grade and gender distribution related percentages of the students taking part in the study are given in Table 1. 
Table 1. The group's grade and gender distribution

\begin{tabular}{ccccccc}
\hline Grade & & Girl & & \multicolumn{2}{c}{ Boy } & \multicolumn{2}{c}{ Total } \\
\hline & $\mathrm{n}$ & $\%$ & $\mathrm{n}$ & $\%$ & $\mathrm{n}$ & $\%$ \\
1 & 27 & 9.2 & 35 & 11.9 & 62 & 21.2 \\
2 & 42 & 14.3 & 48 & 16.4 & 90 & 30.7 \\
3 & 32 & 10.9 & 32 & 10.9 & 64 & 21.8 \\
4 & 43 & 14.7 & 34 & 11.6 & 77 & 26.3 \\
Total & 144 & 49.1 & 149 & 50.9 & 293 & 100 \\
\hline
\end{tabular}

\subsection{Materials and Procedure}

\subsubsection{Personal Information Form}

The personal information form, which was developed by the researchers, consisted of questions on students' gender, grade level, the school they are attending and the level of academic success.

\subsubsection{Kids' Empathic Development Scale—KEDS}

KEDS was developed by Reid et al. (2012) in order to evaluate the affective, cognitive and behavioural aspects of empathy in children 6 to 10 years old. Children are presented with 12 faceless pictographic stimuli and asked to infer and ascribe to a person or persons feelings in specific situations. Regarding to the cards, the following questions were asked: "what do you think this girl is feeling?" (affective), "can you tell me why this girl is feeling like this?" (cognitive), "can you tell me more about what is happening in this picture?" (behavioural) and "what would you do if you were in this girl's position?" (behavioural). The answers were graded as correct and incorrect. In six of the 12 scenarios, two faceless characters were present and questions were asked separately for both (Figure 1). Before starting the questions regarding the scenarios six facial expressions are shown to the children and they were asked to name the feelings on those expressions. The study is concluded right away if the student cannot name the first three feelings out of six (happy, sad, angry, surprised, afraid and relaxed) correctly. In the study conducted by Reid et al. (2012) the Cronbach's alpha internal consistency coefficient was found .63 for affective, .82 for cognitive and .84 for behavioural aspects. The overall fit test of the affect and cognition items revealed a significant deviation from unidimensionality, $\chi_{(16)}^{2}=35.50, \mathrm{p}=.003$ and $\chi_{(28)}^{2}=88.00, \mathrm{p}$ $<.001$ respectively. However, the behaviour scale showed good fit overall, $\chi_{(16)}^{2}=22.45, p=.13$ (Reid et al., 2012).

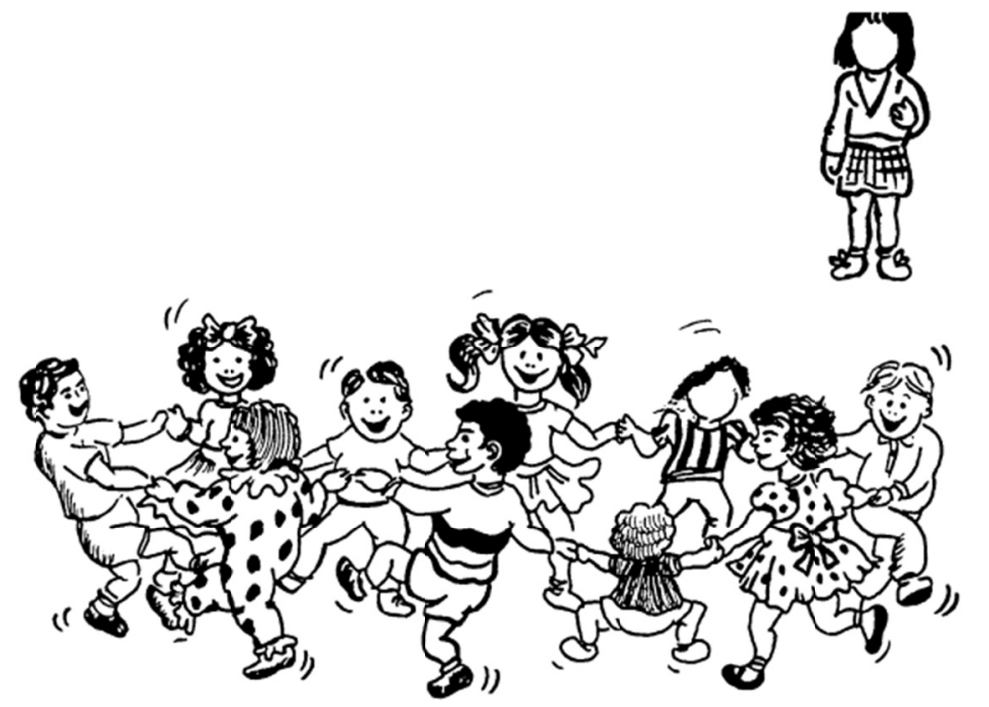

Figure 1. Kids' empathic development scale scenario example: "ring-a-rosie"

\subsubsection{Empathy Scale for Children and Teenagers (ESCT)}

Empathy Scale for Children and Teenagers was developed by Bryant (1982) and was adapted into Turkish by Gürtunca (2013). The scale can be applied to children and teenagers between ages 8 to 14 . The pen and paper scale comprises of 22 items. The lowest obtainable score from the binary response format is 0 , whereas the 
highest is 22. A high score indicates high empathy level. The internal consistency of the scale was calculated as .70 using the KR20 formula (Gürtunca, 2013). In the current study, the same calculation yielded a result of .69 .

\subsection{Data Analysis}

The SPSS 21.0 statistical package was used to compute Wilcoxon Matched Pairs test for English and Turkish forms and Spearman and Pearson Product Moments correlation analyses, while JMETRIK 1.0 was used in order to test Turkish compatibility levels and structure validity.

\section{Results}

\subsection{Translation and Language Validity}

The scale was translated from English to Turkish by three experts. Then, these three different Turkish forms compared by the researcher and combined in a one form. This Turkish form was translated back into English by an expert. This form was observed to be consistent with its English original. Afterward, five language experts were consulted to evaluate the language compatibility between the two forms. The experts were asked to grade the Turkish of an item from 0 to 5 by comparing it to the English version. Even though there are 12 different scenarios in the scale and there are four to seven items for each scenario with a total of 17 items in it, the questions regarding these items are the same, therefore, the translation was not focused on all items, but only to the item roots. Thus, only the item roots were presented to the language experts. According to the experts' opinions, the compatibility level of the items in the scale varies from 4.60 to $5(\bar{X}=4.80, \mathrm{SD}=.44)$. The compatibility levels of item roots are given in Table 2.

Table 2. Compatibility levels of the scale's item roots for the English Turkish translation

\begin{tabular}{lcc}
\hline Item Roots & $\bar{X}$ & SD \\
\hline What do you think this girl is feeling? & 4.8 & 0.44 \\
Can you tell me why this girl is feeling ...? & 4.8 & 0.44 \\
Can you tell me more about what is happening in this picture? & 4.6 & 0.54 \\
What would you do if you were in this girl's position? & 5 & 0.00 \\
\hline
\end{tabular}

After the translation of the scale into Turkish, both of the forms were applied to 30 primary school students three weeks apart. As a result of the Kolmogorov Smirnov test it was determined that the group did not display normal distribution and non-parametric techniques were used (Affective Score: KS (30) =.117, p <.01.; Cognitive Score: KS $(30)=.203, \mathrm{p}<.01$, Behavioural Score: KS $(30)=.197, \mathrm{p}<.01$ Total Score: KS $(30)=.173, \mathrm{p}<.05)$. Wilcoxon Matched Pairs test between the English and Turkish forms' applications and Spearman correlation coefficients were given in Table 3.

Table 3. Wilcoxon matched pairs test between the English and Turkish forms' and Spearman correlation coefficients

\begin{tabular}{|c|c|c|c|c|c|c|c|c|c|c|c|c|c|}
\hline & & $\mathrm{M}$ & SD & $\mathrm{t}$ & $\mathrm{p}$ & $\mathrm{r}$ & & & $\mathrm{M}$ & SD & $\mathrm{t}$ & $\mathrm{p}$ & $\mathrm{r}$ \\
\hline \multirow[t]{8}{*}{ Scenario 2} & Eng2_1 & .933 & .25 & \multirow{2}{*}{-1.00} & \multirow{2}{*}{ - } & \multirow{2}{*}{$.80 * *$} & \multirow[t]{2}{*}{ Scenario 9} & Eng9a_1 & .133 & .345 & \multirow{2}{*}{.000} & \multirow{2}{*}{-} & \multirow{2}{*}{.25} \\
\hline & Tur2_1 & .897 & .309 & & & & & Tur9a_1 & .103 & .309 & & & \\
\hline & Eng2_2 & 1.00 & .37 & \multirow{2}{*}{-1.34} & \multirow{2}{*}{-} & \multirow{2}{*}{.30} & & Eng9a_2 & .867 & .507 & \multirow{2}{*}{-.333} & \multirow{2}{*}{-} & \multirow{2}{*}{.13} \\
\hline & Tur2_2 & 1.10 & .309 & & & & & Tur9a_2 & .897 & .309 & & & \\
\hline & Eng2_3 & .167 & .461 & \multirow{2}{*}{-1.34} & \multirow{2}{*}{-} & \multirow{2}{*}{$.53 * *$} & & Eng9a_3 & .133 & .507 & \multirow{2}{*}{-.447} & \multirow{2}{*}{-} & \multirow{2}{*}{$.48^{* *}$} \\
\hline & Tur2_3 & .034 & 185 & & & & & Tur9a_3 & .103 & .409 & & & \\
\hline & Eng2_4 & .167 & .379 & \multirow{2}{*}{-1.89} & \multirow{2}{*}{-} & \multirow{2}{*}{$.48 * *$} & & Eng9a_4 & .767 & .935 & \multirow{2}{*}{-.258} & \multirow{2}{*}{-} & \multirow{2}{*}{$.59 * *$} \\
\hline & Tur2_4 & .379 & .621 & & & & & Tur9a_4 & .759 & .739 & & & \\
\hline \multirow[t]{8}{*}{ Scenario 3} & Eng3_1 & .800 & .406 & \multirow{2}{*}{-1.34} & \multirow{2}{*}{-} & \multirow{2}{*}{$.38^{*}$} & & Eng9b_1 & .133 & .345 & \multirow{2}{*}{-1.13} & \multirow{2}{*}{-} & \multirow{2}{*}{.24} \\
\hline & Tur3_1 & .897 & .309 & & & & & Tur9b_1 & .241 & .435 & & & \\
\hline & Eng3_2 & 1.13 & .345 & \multirow{2}{*}{.000} & & & & Eng9b_2 & .800 & .484 & & & \\
\hline & Tur3_2 & 1.13 & .350 & & - & $.42^{*}$ & & Tur9b_2 & .966 & .498 & -1.50 & - & .23 \\
\hline & Eng3_3 & .433 & .678 & -212 & $*$ & & & Eng9b_4 & .900 & .884 & & & \\
\hline & Tur3_3 & .172 & .468 & -2.12 & $*$ & $.60^{\mathrm{Nk}}$ & & Tur9b_4 & .828 & .710 & -.211 & - & .23 \\
\hline & Eng3_4 & .467 & .628 & -707 & - & $55 * *$ & Scenario 10 & Eng10_1 & .700 & .466 & -244 & $*$ & $44 *$ \\
\hline & Tur3_4 & .414 & .568 & -.701 & & $.55 \times$ & & Tur10_1 & .931 & .257 & -2.44 & 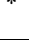 & $.44^{*}$ \\
\hline
\end{tabular}




\begin{tabular}{|c|c|c|c|c|c|c|c|c|c|c|c|c|c|}
\hline \multirow[t]{8}{*}{ Scenario 4} & Eng4_1 & .867 & .345 & \multirow{2}{*}{-.577} & \multirow{2}{*}{-} & \multirow{2}{*}{$.61^{* *}$} & & Eng10_2 & 1.03 & .319 & \multirow{2}{*}{-.707} & \multirow{2}{*}{-} & \multirow{2}{*}{-.33} \\
\hline & Tur4_1 & .828 & .384 & & & & & Tur10_2 & .966 & .325 & & & \\
\hline & Eng4_2 & 1.033 & .319 & \multirow{2}{*}{-1.34} & \multirow{2}{*}{-} & \multirow{2}{*}{\multicolumn{2}{|c|}{.31}} & Eng10_3 & .133 & .345 & \multirow{2}{*}{-.447} & \multirow{2}{*}{-} & \multirow{2}{*}{.19} \\
\hline & Tur4_2 & .931 & .371 & & & & & Tur10_3 & .103 & .309 & & & \\
\hline & Eng4_3 & .300 & .535 & \multirow{2}{*}{-1.66} & \multirow{2}{*}{-} & \multirow{2}{*}{$.60 * *$} & & Eng10_4 & .233 & .504 & 905 & & 03 \\
\hline & Tur4_3 & .448 & .631 & & & & & Tur10_4 & 138 & .350 & -900 & 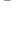 & .00 \\
\hline & Eng4_4 & .533 & .730 & -302 & & $51 * *$ & Scenario 11 & Eng11a_1 & .690 & .470 & -577 & & $75 * *$ \\
\hline & Tur4_4 & .483 & .737 & .002 & 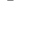 & .01 & & Tur11a_1 & .724 & .454 & 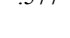 & 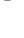 & . \\
\hline Scenario 5 & Eng5a_1 & .800 & .406 & -100 & & $53 * *$ & & Eng11a_2 & .621 & .561 & -129 & & 11 \\
\hline & Tur5a_1 & .862 & .350 & 1.00 & & .00 & & Tur11a_2 & .793 & .491 & 1.25 & & .17 \\
\hline & Eng5a_2 & 1.00 & .262 & -1.00 & - & $72 * *$ & & Eng11a_3 & .172 & .468 & -1.00 & - & $54 * *$ \\
\hline & Tur5a_2 & .966 & .185 & -1.00 & 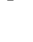 & .12 & & Tur11a_3 & .103 & .309 & -1.00 & 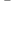 & (6) \\
\hline & Eng5a_3 & .233 & .504 & -141 & & $88 * *$ & & Eng11a_4 & .655 & .814 & -690 & & $55^{* *} *$ \\
\hline & Tur5a_3 & .138 & .350 & -1.71 & 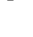 & .00 & & Tur11a_4 & .759 & .786 & .070 & 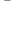 & (J) \\
\hline & Eng5a_4 & .867 & .479 & -966 & & $57 * *$ & & Eng11b_1 & .276 & .454 & -163 & & $57 * *$ \\
\hline & Tur5a_4 & .966 & .905 & 年 & 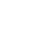 & (1) & & Tur11b_1 & .414 & .501 & -1.00 & 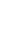 & . \\
\hline & Eng5b_1 & .667 & .479 & 000 & - & -12 & & Eng11b_2 & .862 & .693 & 000 & - & $83 * *$ \\
\hline & Tur5b_1 & .690 & .470 & 800 & & . & & Tur11b_2 & .862 & .639 & 000 & & .00 \\
\hline & Eng5b_2 & 1.10 & .402 & -1.63 & - & $42 *$ & & Eng11b_4 & .483 & .574 & -.707 & - & $60 * *$ \\
\hline & Tur5b_2 & .966 & .421 & 1.00 & & .72 & & Tur11b_4 & .552 & .572 & 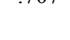 & 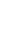 & .00 \\
\hline & Eng5b_4 & .800 & .846 & -1.07 & - & $52 * *$ & Scenario 12 & Eng12_1 & .586 & .501 & -905 & - & 19 \\
\hline & Tur5b_4 & .931 & .842 & 1.07 & 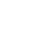 & .02 & & Tur12_1 & .690 & .470 & .900 & 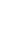 & .14 \\
\hline Scenario 6 & Eng6_1 & .400 & .498 & -253 & $*$ & $41 *$ & & Eng12_2 & 1.03 & .565 & -447 & - & $71 * *$ \\
\hline & Tur6_1 & .690 & .470 & 2.00 & & .71 & & Tur12_2 & 1.06 & .529 & וד. & 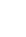 & .71 \\
\hline & Eng6_2 & .900 & .305 & -1.00 & - & -.06 & & Eng12_3 & .138 & .441 & -.447 & - & $45^{*}$ \\
\hline & Tur6_2 & .966 & .185 & -1.00 & & .00 & & Tur12_3 & .172 & .384 & ו דד. & 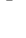 & .45 \\
\hline & Eng6_3 & .167 & .379 & -1.13 & - & -.12 & & Eng12_4 & .414 & .568 & -1.34 & - & $.74 * *$ \\
\hline & Tur6_3 & .069 & .257 & & 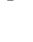 & -12 & & Tur12_4 & .517 & .687 & -1.04 & - & .14 \\
\hline & Eng6_4 & .333 & .546 & -1.66 & - & $.39 *$ & Scenario 13 & Eng13a_1 & .552 & .506 & -.302 & - & .22 \\
\hline & Tur6_4 & .138 & .350 & & & - & & Tur13a_1 & .586 & .501 & & & \\
\hline Scenario 7 & Eng7_1 & .667 & .479 & -2.11 & $*$ & .31 & & Eng13a_2 & 1.13 & .515 & -1.13 & - & $.60^{* *}$ \\
\hline & Tur7_1 & .414 & .501 & & & & & Tur13a_2 & 1.03 & .565 & & & \\
\hline & Eng7_2 & 1.03 & .319 & -.447 & - & .29 & & Eng13a_3 & .207 & .559 & -1.89 & - & $.50 * *$ \\
\hline & Tur7_2 & 1.00 & .378 & & & & & Tur13a_3 & .034 & .185 & 1.03 & & \\
\hline & Eng7_3 & .133 & .345 & -1.00 & - & .28 & & Eng13a_4 & .586 & .732 & -.707 & - & $.72 * *$ \\
\hline & Tur7_3 & .069 & .257 & & & & & Tur13a_4 & .655 & .720 & & 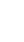 & \\
\hline & Eng7_4 & .733 & .691 & -.632 & - & $.66^{* *}$ & & Eng13b_1 & .759 & .435 & -.816 & - & $.38^{*}$ \\
\hline & Tur7_4 & .690 & .541 & & & & & Tur13b_1 & .828 & .384 & & & \\
\hline Scenario 8 & Eng8a_1 & .966 & .185 & .000 & - & $1.00 * *$ & & Eng13b_2 & .897 & .673 & -2.33 & $*$ & $.68^{* *}$ \\
\hline & Tur8a_1 & .966 & .185 & & & & & Tur13b_2 & 1.13 & .639 & & & \\
\hline & Eng8a_2 & 1.20 & .491 & -1.73 & - & $.76^{* *}$ & & Eng13b_4 & 1.00 & .925 & -.905 & - & $.66^{* *}$ \\
\hline & Tur8a_2 & 1.10 & .409 & & & & & Tur13b_4 & .897 & .939 & & & \\
\hline & Eng8a_3 & .276 & .591 & -378 & - & $67 * *$ & & & & & & & \\
\hline & Tur8a_3 & .241 & .435 & .070 & & & & & & & & & \\
\hline & Eng8a_4 & .690 & .890 & -.881 & - & $.51^{* *}$ & & & & & & & \\
\hline & Tur8a_4 & .828 & .804 & & & & & & & & & & \\
\hline & Eng8b_1 & .862 & .350 & -.816 & - & .28 & & & & & & & \\
\hline & Tur8b_1 & .793 & .412 & S & & .20 & & & & & & & \\
\hline & Eng8b_2 & 1.17 & .539 & -1.41 & - & $.57 * *$ & & & & & & & \\
\hline & Tur8b_2 & 1.03 & .565 & & & & & & & & & & \\
\hline & Eng8b_4 & .621 & .902 & -1.26 & - & $.89 * *$ & & & & & & & \\
\hline & Tur8b_4 & .759 & .912 & & & & & & & & & & \\
\hline
\end{tabular}

Note. $* \mathrm{p}<.05, * * \mathrm{p}<.01$

As seen from Table 3, there is only one problematic item in both Wilcoxon Matched Pairs test and Spearman correlations: I7_1. In order to preserve the integrity of the scale, it was decided to keep or remove this item after the reliability analysis. 


\subsection{Reliability Study}

In order to calculate the internal consistency of the scale, Kuder-Richardson (KR-20) method was used. As mentioned before the responses provided by the students were 0 or 1 , therefore this method was adopted (Gürsakal, 2001). The KR-20 internal consistency coefficients were calculated as follows: total empathy score .92 , total affective score .91 , total cognitive score .87 and total behavioural score .97 . Since these results were satisfactory, and removing the aforementioned item did not change the reliability coefficients, it was decided to keep item I7_1 in the scale.

\subsection{Validity Study}

Rasch Analysis Results. The internal structure validity of the scale was evaluated using the Rasch model (Wright \& Stone, 1979). Rasch analysis assumes the data in the scale to be one dimensional and evaluates their compatibility level to one dimension. To test the data's compatibility with one parameter ordering model is equivalent to evaluating the scale's theoretic structural validity and compatibility (Wright \& Stone, 1979). Item functioning is examined using a combination of statistics, including infit and outfit Mean Square (MnSq), where infit MnSq is the information-weighted squared residuals and outfit $\mathrm{MnSq}$ are unweighted squared residuals. Both infit and outfit $\mathrm{MnSq}$ are a measure of the consistency that items are used by raters with expected values being close to 1.0, representing perfect fit between responses and the Rach model (Meyer, 2014). However, acceptable MnSq values are .8-1.2 (excellent fit) (Bond \& Fox, 2007), .5-1.5(acceptable fit) (Linacre, 2014). In this study, these values were taken into account (Tables 4, 5 and 6).

Table 4. Infit and outfit compatibility of affective subscale items according to Rasch analysis and differential item functioning

\begin{tabular}{llll}
\hline Items & DIF & Infit & Outfit \\
\hline Item 2_1 & $\mathrm{A}$ & 1.02 & 1.24 \\
Item 3_1 & $\mathrm{A}$ & 1.03 & 1.09 \\
Item 4_1 & $\mathrm{A}$ & 1.03 & 1.14 \\
Item 5a_1 & $\mathrm{A}$ & .94 & .88 \\
Item 5b_1 & $\mathrm{A}$ & .94 & .87 \\
Item 6_1 & $\mathrm{A}$ & 1.02 & 1.01 \\
Item 7_1 & $\mathrm{A}$ & 1.08 & 1.10 \\
Item 8a_1 & $\mathrm{A}$ & .93 & .89 \\
Item 8b_1 & $\mathrm{A}$ & 1.05 & 1.12 \\
Item 9a_1 & $\mathrm{A}$ & 1.09 & 1.24 \\
Item 9b_1 & $\mathrm{B}-$ & .89 & .88 \\
Item 10_1 & $\mathrm{A}$ & .1 .02 & 1.00 \\
Item 11a_1 & $\mathrm{A}$ & .84 & .83 \\
Item 11b_1 & $\mathrm{A}$ & .89 & .83 \\
Item 12_1 & $\mathrm{A}$ & 1.06 & 1.13 \\
Item 13a_1 & $\mathrm{B}-$ & 1.19 & 1.24 \\
Item 13b_1 & $\mathrm{A}$ & 1.21 & 1.32 \\
\hline
\end{tabular}

Table 5. Infit and outfit compatibility of cognitive subscale items according to Rasch analysis and differential item functioning

\begin{tabular}{llll}
\hline Items & DIF & Infit & Outfit \\
\hline Item 2_2 & A & .94 & .92 \\
Item 2_3 & A & 1.02 & 1.02 \\
Item 3_2 & A & .96 & .98 \\
Item 3_3 & A & 1.05 & 1.06 \\
Item 4_2 & A & 1.00 & 1.01 \\
Item 4_3 & B & 1.11 & 1.11 \\
Item 5a_2 & A & .88 & .86 \\
Item 5a_3 & A & 1.25 & 1.26 \\
Item 5b_2 & A & .92 & .92 \\
Item 6_2 & A & .90 & .85 \\
Item 6_3 & A & .94 & .94 \\
Item 7_2 & A & .94 & .96 \\
Item 7_3 & A & 1.03 & 1.04 \\
\hline
\end{tabular}




\begin{tabular}{llll}
\hline Item 8a_2 & A & .89 & .87 \\
Item 8a_3 & $\mathrm{A}$ & 1.14 & 1.14 \\
Item 8b_2 & $\mathrm{A}$ & .98 & .96 \\
Item 9a_2 & $\mathrm{A}$ & .95 & .91 \\
Item 9a_3 & $\mathrm{B}+$ & 1.04 & 1.01 \\
Item 9b_2 & $\mathrm{A}$ & .95 & .96 \\
Item 10_2 & $\mathrm{A}$ & 1.01 & 1.06 \\
Item 10_3 & $\mathrm{A}$ & .88 & .86 \\
Item 11a_2 & $\mathrm{A}$ & .93 & .93 \\
Item 11a_3 & $\mathrm{A}$ & 1.07 & 1.08 \\
Item 11b_2 & $\mathrm{A}$ & .95 & .95 \\
Item 12_2 & $\mathrm{B}-$ & .96 & .96 \\
Item 12_3 & $\mathrm{B}+$ & 1.19 & 1.20 \\
Item 13a_2 & $\mathrm{A}$ & .92 & .93 \\
Item 13a_3 & $\mathrm{A}$ & 1.10 & 1.12 \\
Item 13b_2 & $\mathrm{A}$ & 1.05 & 1.04 \\
\hline
\end{tabular}

Table 6. Infit and outfit compatibility of behavioural subscale according to Rasch analysis and differential item functioning

\begin{tabular}{llcc}
\hline Items & DIF & Infit & Outfit \\
\hline Item 2_4 & $\mathrm{A}$ & 1.12 & 1.30 \\
Item 3_4 & $\mathrm{A}$ & 1.12 & 1.36 \\
Item 4_4 & $\mathrm{A}$ & .96 & .97 \\
Item 5a_4 & $\mathrm{A}$ & .84 & .84 \\
Item 5b_4 & $\mathrm{A}$ & .86 & .82 \\
Item 6_4 & $\mathrm{A}$ & 1.20 & 1.33 \\
Item 7_4 & $\mathrm{A}$ & 1.20 & 1.21 \\
Item 8a_4 & $\mathrm{A}$ & .86 & .86 \\
Item 8b_4 & $\mathrm{B}+$ & .94 & .93 \\
Item 9a_4 & $\mathrm{A}$ & .95 & .94 \\
Item 9b_4 & $\mathrm{A}$ & .87 & .86 \\
Item 10_4 & $\mathrm{A}$ & 1.19 & 1.46 \\
Item 11a_4 & $\mathrm{B}+$ & .94 & .89 \\
Item 11b_4 & $\mathrm{A}$ & .96 & .93 \\
Item 12_4 & $\mathrm{A}$ & 1.20 & 1.20 \\
Item 13a_4 & $\mathrm{A}$ & .90 & .87 \\
Item 13b_4 & $\mathrm{B}-$ & .97 & .96 \\
\hline
\end{tabular}

As seen from Tables 4, 5 and 6 all items fit into either A, B+ or B- categories. As Meyer (2014) stated it is not necessary to remove items from the scale unless they fit in the C category. However, since B+ and B- items still need to be reviewed the internal consistency coefficient was re-evaluated without these items and no difference was observed. Because of this and to preserve the original structure of the scale the items were kept.

Convergent and discriminant validity. In order to determine the validity of the scale its concurrent validity was tested (Karakoç \& Dönmez, 2014). The evaluations of Empathy Scale in Children and Teenagers (ESCT) were taken as a criterion and Pearson Product Moment correlation coefficients between the two scales were analyzed. The results are given in Table 7.

Table 7. Correlation analysis between KEDS and ESCT

\begin{tabular}{lllll}
\hline $\mathrm{n}=293$ & 2 & 3 & 4 & 5 \\
\hline 1 Affective & $.143^{*}$ & .064 & $.500^{* *}$ & .113 \\
2 Cognitive & & $.144^{*}$ & $.680^{* *}$ & $.149^{*}$ \\
3 Behavioural & & & $.719^{* *}$ & .065 \\
4 Total Empathy & & & $.164^{* *}$ \\
5 ESCT & & & \\
\hline$<$.1 & & &
\end{tabular}

$* \mathrm{p}<.05, * * \mathrm{p}<.01$. 
There are not many scales in our country which can evaluate empathy in young ages. Therefore, the Empathy Scale in Children and Teenagers (ESCT), adapted by Gürtunca (2013), was applied in order to test its correlation with KEDS. Pearson Product Moment correlation analysis tells us there is a meaningful positive correlation between the total scores of the two scales $(\mathrm{p}<.01)$. Moreover, KEDS' cognitive score also has a significant positive correlation with ESCT $(\mathrm{p}<.05)$.

In order to check whether or not the dimensions of the scale are separable the relation between the three subscales was tested. According to these studies affective subscale scores had a positive correlation $.14(\mathrm{p}<.05)$ with cognitive subscale scores and $.06(\mathrm{p}>.05)$ with behavioural subscale scores. A positive correlation of $.14(\mathrm{p}$ $<.05$ ) was detected between the cognitive subscale scores and behavioural subscale scores. The results showed that affective dimension and cognitive dimension overlap a little as well as cognitive subscale and behavioural subscale. Moreover, all subscales had a positive correlation with the total empathy score $(\mathrm{p}<.01)$. These findings confirm the results of the original study conducted by Reid et al., (2012).

Results of the two-way variance analysis which was performed to check whether the empathy scores changed with the age variable or not were obtained as follows: total empathy score $\mathrm{F}_{(1,142)}=11.12, \mathrm{p}<.05$; affective $\mathrm{F}_{(1 \text {, }}$ ${ }_{140)}=5.63, \mathrm{p}<.05$; cognitive $\mathrm{F}_{(1,143)}=8.6, \mathrm{p}<.01$ and behavioural $\mathrm{F}_{(1,142)}=16.71, \mathrm{p}<.001$. When the gender variable was considered no significant results were obtained in either subscale. Age and gender interaction was not found to have a significant effect like it did in the original English version of the scale: $\left(\mathrm{F}_{(1,142)}=3.38\right.$, p > .05) (Table 8). Since only the ages seven and nine were taken into account in Reid et al. (2012)'s study, the analyses were performed only on these ages.

Table 8. Means (SD) scores on KEDS scales by age and gender

\begin{tabular}{lllllll}
\hline Age & Gender & n 144 & $\begin{array}{l}\text { Affect } \\
\text { (Max 23) }\end{array}$ & $\begin{array}{l}\text { Cognition } \\
\text { (Max 41) }\end{array}$ & $\begin{array}{l}\text { Behavioural } \\
\text { (Max 27) }\end{array}$ & $\begin{array}{l}\text { Total } \\
(\text { Max 81) }\end{array}$ \\
\hline 7 & Boy & 44 & $15.58(3.73)$ & $20.90(4.53)$ & $11.17(5.96)$ & $45.20(8.51)$ \\
& Girl & 38 & $16.25(3.16)$ & $23.25(5.20)$ & $11.83(6.17)$ & $49.32(9.27)$ \\
9 & Boy & 31 & $14.75(3.67)$ & $25.40(5.18)$ & $12.90(5.99)$ & $53.06(9.28)$ \\
& Girl & 31 & $14.15(3.94)$ & $23.73(5.03)$ & $51.59(6.18)$ & $51.59(8.61)$ \\
\hline
\end{tabular}

\section{Discussion and Conclusion}

Kids' Empathic Development Scale (KEDS) designed to assess affective, cognitive and behavioural components of empathy of young children (6 to 10 years old). KEDS' differs from other empathy scales by combining three techniques: emotion recognition, picture-based scenarios and behavioural self-report. The aim of this study was to present the Turkish validity study of the scale and to provide a new tool that has satisfactory psychometric properties. The results of the study showed that the Turkish version of KEDS is a valid and reliable measurement.

We reported on a language validation study of the KEDS. The language validation study comprised three steps. First, five language experts made the translation and back translation of the scale. Secondly, bilingual group administered first Turkish and three weeks later the English version of the scale, the paired samples t-test, and Pearson product-moment correlation coefficient analysis were reported. Thirdly we looked at the convergent and discriminant validity. The adaptation degrees for the translated items were higher enough to administer the scale to the bilingual group. According to the results of paired samples t-test, which was acquired to define language equivalency of the scale items, no significant differences were found between the responses to English and Turkish versions except on item I7_1. The results of the Pearson product-moment correlation coefficient analysis which was obtained to define item-total and item-reminder found statistically positive correlations of all items.

The positive correlation between Total Scores of Kids' Empathic Development Scale and Total Score of Empathy Scale in Children and Teenagers, which is another scale that evaluates empathy, signifies that they measure the same structures. However, only the cognitive subscale is related to the Empathy Scale in Children and Teenagers, which means that the other subscales are distinct. Moreover, the finding that the three subscales in the scale, (i.e. affective, cognitive and behavioural), had low correlation with each other, showed that they are discreet constructs. This finding supports the results of the original study conducted by Reid et al., 2012.

Study results also showed that empathy subscales change with the age. It can be seen that the study's results are consistent with the results of Reid et al. (2012)' study. There are meaningful differences between the total score and subscales according to the age variable, in the current study this is in favor of the older children. 
Unfortunately, no other studies could be found in our country regarding the empathy of such young children. The increase in empathy skill along with age is a part of emotional development (Kabapınar, 2015). However, developing training programs to increase empathy skills of children is a topic that must be emphasized. Thus, it is recommended that researchers should focus their further studies to develop training programs to increase more effectively the empathy skills of the students.

The results of our language validation study can be summarized as follows. The adaptation degree was high enough for each item. The paired sample t-test (except I7_1) and the Pearson product moment correlation coefficient results indicated that the two forms are equal. The convergent and discriminant validity were satisfying. It is thought that it could be beneficial if future studies could find out if the scale is effected by variables such as, intelligence, socioeconomic level of the family, education level of the parents etc. Especially the intelligence variable is viewed as an important variable because it may help design training programs for gifted children. The experimental study conducted by Kurt (2018) was an attempt for such a study. He developed a bibliotherapy based training program to increase empathy skills of gifted students. Other studies may search the effects of such programs to academic success and to life success and wellbeing.

Yalçın and Yalçın (2018) stated that empathy is an important skill for the kindergarten and primary school students to understand better the feelings and lives of inclusion students, who need special education. Migration is another important topic for countries such as Turkey, that have to meet immigrants in everyday life, especially in schools. As Türk, Kaçmaz, Türnüklü and Tercan (2018) mentioned, empathy is a fundamental skill to develop communication for students who have immigrants in their classrooms. Further studies that will use Kids' Empathic Development Scale may provide an insight for the school counselors about the empathy skills of their students.

Last but not least, a scale used in evaluating empathy (ESCT) is the pen and paper scale, therefore it is thought that students have answered it sincerely. This can be thought of as one of the limitations of this study. Current analysis findings showed that Kids' Empathic Development Scale's (developed by Reid et al., 2012) Turkish form is a valid and reliable tool. Therefore, this scale which provides the evaluation of empathy in children of school age by utilizing many scenarios was adapted into Turkish in accordance with its English original. It is hoped that the results of this study will provide information to educators about affective, cognitive and behavioural aspects of empathy skills of young children.

\section{Acknowledgments}

The authors would like to thank Dr. Reid and her team for giving the permission to use the scale and all the participants for their motivation and effort. A special thanks to Halide Nur Uğurluoğlu for her help to collect the data.

\section{References}

Bal, P. N., \& Bilge, Y. (2016). The effect of empathy skills psycho training program on gifted adolescents. Journal of Hasan Ali Yücel Faculty of Education, 13, 23-36.

Barnett, M. A. (1990). Empathy and related responses in children. In N. Eisenberg \& J. Strayer (Eds.), Empathy and its development (pp. 146-163). Cambridge: Cambridge University Press.

Bischof-Köhler, D. (1991). The development of empathy in infants. In M. E. Lamb \& H. Keller (Eds.), Infant Development: Perspectives from German-Speaking Countries. NJ: LAE.

Bond, T. G., \& Fox, C. M. (2007). Applying the Rasch model: fundamental measurement in the human sciences. Mahwah: NJ: Lawrebce Erlbaum.

Bonner, D., \& Aspy, D. (1984). A study of the relationship between student empathy and GPA. Humanistic Education and Development, 149-153. https://doi.org/10.1002/j.2164-4683.1984.tb00252.x

Bryant, B. K. (1982). An index of empathy for children and adolescents. Child Development, 53, 413-425. https://doi.org/10.2307/1128984

Cappadocia, M. C., Pepler, D., Cummings, J. G., \& Craig, W. (2012). Individual motivations and characteristics associated with bystander intervention during bullying episodes among children and youth. Canadian Journal of School Psychology, 27, 201-216. https://doi.org/10.1177/0829573512450567

Cooper, B. (1997). Teaching Empathy. Plymouth University: SPES.

Cooper, B. (2011). Empathy in education: engagement, values and achievement. Great Britain: Continuum International Publishing Group. 
Costa, G., Glinia, E., \& Drakou, A. (2006). The role of empathy in sport tourism services: a review. Journal of Sport and Tourism, 4, 331-342. https://doi.org/10.1080/1477508052000341887

Davis, M. (1980). A multidimensional approach to individual differences in empathy. Catalogue of Selected Documents in Psychology, 10(85).

Demetriou, H. (2018). Empathy, Emotion and Education. UK: Springer. https://doi.org/10.1057/978-1-137-54844-3

Dökmen, Ü. (1988). Empatinin yeni bir modele dayanılarak ölçülmesi ve psikodarama ile geiliştirilmesi. A.Ü. Eğitim Bilimleri Fakültesi Dergisi, 2(1-2), 155-190.

Eisenberg, N., \& Fabes, R. A. (1990). Empathy: conceptualization, measurement, and relation to prosocial behavior. Motivation and Emotion, 14(2), 131-149. https://doi.org/10.1007/BF00991640

Feshbach, N. D. (1978). Studies of empathic behavior in children. In B. A. Maher (Ed.), Progress in experimental personality research. NY: Academic Press.

Feshbach, N. D., \& Feshbach, S. (1987). Affective processes and academic achievement. Child Development, 58, 1335-1347. https://doi.org/10.2307/1130625

Feshbach, N. D., \& Feshbach, S. (2009). Empathy and education. In J. Decety and W. Ickes (Eds.), The Social Neuroscience on Empathy. USA: MIT Press. https://doi.org/10.7551/mitpress/9780262012973.003.0008

Feshbach, N. D., \& Kuchenbecker, S. Y. (1974). A three-component model of empathy. Annual Meeting of the American Psychological Association. September 1974 New Orleans, LA. 1-13.

Gemci, H. (2012). Illköğretim 8. Sinlf öğrencilerine Uygulanan İletişim ve Empatik Beceri Ĕ̈itiminin Öğrencilerin İletişim ve Empatik Becerilerine Etkisinin İncelenmesi. (Yüksek Lisans), Dokuz Eylül Üniversitesi.

Gini, G., Albiero, P., Benelli, B., \& Altoe, G. (2007). Does empathy predict adolescents' bullying and defending behavior? Agressive Behavior, 33(5), 467-476. https://doi.org/10.1002/ab.20204

Goleman, D. (2000). Duygusal zeka. İstanbul: Varlık Yayınları.

Gökler, R. (2009). Empatik Eğilim Ölçeğinin İlköğretim Sekizinci Sınıflar İçin Uyarlanması. Sosyal Politika Çalışmaları Dergisi, 19(19).

Gürsakal, N. (2001). Sosyal bilimlerde araşttrma yöntemleri. Bursa: Uludağ Üniversitesi Güçlendirme Vakfı Yayınları.

Gürtunca, A. (2013). Çocuklar ve ergenler için empati ölçeği Türkiye geçerlik ve güvenirlik çalışması. (Yüksek Lisans Tezi), Arel Üniversitesi, İstanbul.

Hoffman, M. L. (2000). Empathy and moral development. New York: Cambridge University Press. https://doi.org/10.1017/CBO9780511805851

İşçil, N. (1973). İstatistik metotları ve uygulamaları. Ankara: A.İ.T.İ.A Yayınları.

Jolliffe, D., \& Farrington, D. P. (2006). Development and validation of the basic empathy scale. Journal of Adolescence, 29, 589-611. https://doi.org/10.1016/j.adolescence.2005.08.010

Kabapınar, Y. (Ed.). (2015). Empatiyle Gelişmek Empatiyi Geliştirmek: Çocuk ve Empati. Ankara: Pegem Akademi.

Karakoç, F. Y., \& Dönmez, L. (2014). Ölçek geliştirme çalışmalarında temel ilkeler. Tip Eğitimi Dünyası (40), 39-49. https://doi.org/10.25282/ted.228738

Karasar, N. (1994). Bilimsel araştırma yöntemleri. Ankara: Nobel Yayın Dağııım.

Kaya, A., \& Siyez, D. M. (2010). KA-Sİ çocuk ve ergenler için empatik eğilim ölçeği: geliştirilmesi geçerlik ve güvenirlik çalışması. Eğitim ve Bilim, 35(156), 111-125.

Kurt, T. (2018). Bibliyoterapi yönteminin üstün zekalı ve yetenekli çocukların empati düzeyine etkisi. MA Thesis, Bahcesehir Üniversitesi, İstanbul.

Linacre, J. M. (2014). WINSTEPS Rasch measurement computer program. Beaverton, Oregon: Winsteps.

Lombardo, M. V., Barnes, J. L., Wheelwright, S., \& Baron-Cohen, S. (2007). Self-referential cognition and empathy in autism. PLoS One, 2(9), 883. https://doi.org/10.1371/journal.pone.0000883

Meyer, P. J. (2014). Applied measurement with JMETRIK. USA: New York: Routhledge. 
Mozakoğlu, M. (2015). Teacher, positive classroom and empathy. In Y. Kabapınar (Ed.), Developing With Empathy, Developing Empathy: Children and Empathy. Ankara: Pegem Yayınları.

Padilla-Walker, L. M., \& Christensen, K. J. (2010). Empathy and Self-Regulation as Mediators Between Parenting and Adolescents Prosocial Behavior Toward Strangers, Friends and Family. Journal of Research on Adolescence, 1-11. https://doi.org/10.1111/j.1532-7795.2010.00695.x

Raine, A., \& Chen, F. R. (2017). The Cognitive, Affective, and Somatic Empathy Scales (CASES) for children. Journal of Clinical Child \& Adolescent Psychology, 47(1), 24-37. https://doi.org/10.1080/15374416.2017.1295383

Reid, C., Davis, H., Horlin, C., Anderson, M., Baughman, N., \& Campbell, C. (2012). The Kids' empathic development scale (KEDS): a multi-dimensional measure of empathy in primary school-aged children. British Journal of Developmental Psychology, 31(2), 231-256. https://doi.org/10.1111/bjdp.12002

Roth-Hanania, R., Davidov, M., \& Zahn-Waxler, C. (2011). Empathy development form 8 to 16 months: early signs of concern for others. Infant Behavior and Development, 34(3), 447-458. https://doi.org/10.1016/j.infbeh.2011.04.007

Schrandt, J. A., Townsend, D. B., \& Poulson, C. L. (2013). Physical activity in homes 13 teaching empathy skills to children with autism. Journal of Applied Behavior Analysis, 42(1), 17-32. https://doi.org/10.1901/jaba.2009.42-17

Shapiro, L. E. (2000). Yüksek EQ'lu çocuk yetiştirmek: anne babalar için duygusal zeka rehberi. İstanbul: Varlık Yayınları.

Türk, F., Kaçmaz, T., Türnüklü, A., \& Tercan, M. (2018). Intergroup empathy levels of Turkish and Syrian primary school students from the perspective of school psychological counselors. Elementary Education Online, 17(2), 786-811.

Wright, B. D., \& Stone, M. H. (1979). Best test design. Chicago: Mesa Press.

Yalçın, F. A., \& Yalçın, M. (2018). Preschool teachers' views of ereschool educational problems: Agri city sample. Elementary Education Online, 17(1), 367-383.

Yıldırım, A., \& Şimşek, M. (2008). Sosyal bilimlerde nitel araştırma yöntemleri. Ankara: Seçkin Yayıncılık.

Yüksel, A. (2004). Empati eğitim programının ilköğretim öğrencilerinin empatik becerilerine etkisi. Uludăg Üniversitesi Eğitim Fakültesi Dergisi, 17(2), 341-354.

Zahn-Waxler, C., Radke-Yarrow, K., Wagner, E., \& Chapman, M. (1992). Development of concern for others. Developmental Psychology, 28, 126-136. https://doi.org/10.1037/0012-1649.28.1.126

\section{Copyrights}

Copyright for this article is retained by the author, with first publication rights granted to the journal.

This is an open-access article distributed under the terms and conditions of the Creative Commons Attribution license (http://creativecommons.org/licenses/by/4.0/). 